\title{
EXTENSIONS OF INEQUALITIES INVOLVING KANTOROVICH CONSTANT
}

\author{
MAREK NIEZGODA
}

Abstract. In this paper, two methods of extending inequalities involving Kantorovich constant are presented. An inequality of Mićić et al. [Linear Algebra Appl., 318 (2000), 87-107] on positive linear maps and geometric mean of positive definite matrices is extended to arbitrary matrices having accretive transformation. A result of Dragomir [JIPAM 5 (3), Art.76, 2004] is applied to give new sufficient conditions for Greub-Reinboldt's inequality to hold.

Mathematics subject classification (2010): 15A45, 15A48, 15A42.

Keywords and phrases: Positive linear map, geometric mean of matrices, accretive operator, singular values, vectorial interval.

\section{REFERENCES}

[1] T. Ando, C.-K. Li And R. Mathias, Geometric means, Linear Algebra Appl., 385 (2004), 305334.

[2] R. Bhatia, Matrix Analysis, Springer-Verlag, New York, 1997.

[3] S.S. DRAGOMIR, Reverses of Schwarz, triangle and Bessel inequalities in inner product spaces, J. Ineq. Pure \& Appl. Math., 5, 3 (2004), Article 76.

[Online: http://jipam.vu.edu.au/article.php?sid=368].

[4] S. S. Dragomir, Some Grüss type inequalities in inner product spaces, J. Ineq. Pure \& Appl. Math., 4, 2 (2003), Article 42. [Online: http://jipam.vu.edu . au/article.php?sid=280].

[5] S. S. DRAGOMIR, New inequalities of the Kantorovich type for bounded linear operators in Hilbert spaces, Linear Algebra Appl., 428 (2008), 2750-2760.

[6] S. S. DRAGOMIR, Inequalities for the numerical radius, the norm and the maximum of the real part of bounded linear operators in Hilbert spaces, Linear Algebra Appl., 428 (2008), 2980-2994.

[7] N. Elezović, L. Marangunić And J. PeČArić, Unified treatment of complemented Schwarz and Grüss inequalities in inner product spaces, Math. Inequal. Appl., 8, 2 (2005), 223-231.

[8] M. Fuji, S. Izumino, R. Nakamoto And Y. Seo, Operator inequalities related to CauchySchwarz and Hölder-McCarthy inequalities, Nihonkai Math. J., 8 (1997), 117-122.

[9] A. Giovagnoli And H.P. WynN, G-majorization with applications to matrix orderings, Linear Algebra Appl., 67 (1985), 111-135.

[10] E.-Y. LEE, A matrix reverse Cauchy-Schwarz inequality, Linear Algebra Appl., 430 (2009), 805-810.

[11] J. MićIĆ, J. PEČARIĆ AND Y. SEO, Complementary inequalities to inequalities of Jensen and Ando based on the Mond-Pečarić method, Linear Algebra Appl., 318 (2000), 87-107.

[12] B. Mond And J. PeČARIĆ, Matrix inequalities for convex functions, J. Math. Anal. Appl., 209 (1997), 147-153.

[13] M. S. Moslehian And L. E. Persson, Reverse Cauchy-Schwarz inequalities for positive $C^{*}$-valued sesquilinear forms, Math. Inequal. Appl., 12, 4 (2009), 701-709.

[14] M. NieZgoda, Commutators and accretive operators, Linear Algebra Appl., 431 (2009), 1192-1198.

[15] M. NiezGodA, Accretive operators and Cassels inequality, Linear Algebra Appl., 433 (2010), 136142.

[16] M. NiEzGODA, Kantorovich type inequalities for ordered linear spaces, Electron. J. Linear Algebra, 20 (2010), 103-114. 
[17] T. YAMAZAKI, An extension of Kantorovich inequality to $n$-operators via the geometric mean by Ando-Li-Mathias, Linear Algebra Appl., 416 (2006), 688-695. 